\title{
Agnieszka Cybal-Michalska, Katarzyna Segiet, Klaudia Węc (red.), Aktywizacja młodzieży w warunkach zmiennej rzeczywistości społeczno-kulturowej, Poznań 2021
}

\section{Wprowadzenie}

Młodzież stanowi ważną kategorię badań w naukach społecznych, w tym także w pedagogice, która zajmuje się różnymi aspektami wychowania i socjalizacji młodych ludzi w różnego typu środowiskach. Jednym $\mathrm{z}$ aspektów procesów socjalizacyjnych jest aktywizacja młodzieży w różnych sferach funkcjonowania społecznego, edukacyjnego czy kulturalnego w kontekście zmieniającej się dynamicznie rzeczywistości społeczno-kulturowej. Młodzież „chłonie” otaczający świat - zmiany zachodzące w skali globalnej, lokalnej, które odnoszą się do wszystkich sfer funkcjonowania życia społecznego, rodzinnego, szkolnego, rówieśniczego czy kulturalnego. W badaniach pedagogicznych, zwłaszcza pedagogiki społecznej, bardzo ważne jest aktywizowanie „sił” tkwiących w pojedynczych jednostkach/młodych ludziach, a także w młodzieży jako grupie społecznej wchodzącej w skład struktury społecznej danej społeczności, wspólnoty. Aktywizowanie młodych ludzi do aktywności to jedno z zadań pedagogiki, która podkreśla podmiotowe/sprawcze działania jednostki, jej uczestnictwo bądź współuczestnictwo w procesie własnego rozwoju, rozwoju grupy, do której przynależy, a także szerszej społeczności.

Diagnoza różnego typu aktywności młodzieży w swoim środowisku życia pozwala pedagogom/ animatorom na wsparcie tych aktywności oraz na rozwijanie u młodych ludzi postaw twórczych, samodzielnych w podejmowanych przez nich działaniach.

Przedstawione do recenzji opracowanie wpisuje się w problematykę młodzieży, jej aktywizacji w wymiarze indywidualnym i społecznym, która związana jest z rzeczywistością społeczno-kulturową, w jakiej żyją współcześni młodzi ludzie. Należy dodać, że owa rzeczywistość jest dynamiczna, zmieniająca się, przez co stwarza młodzieży nowe wyzwania, które młodzi ludzie powinni podejmować i się w nie angażować. Dużą rolę w tym zakresie należy przypisać pedagogice, edukacji, zadaniem których powinno być zachęcanie, motywowanie młodych ludzi do aktywnego uczestnictwa w różnego typu działaniach (aktywnościach): na rzecz własnego rozwoju, a także rozwoju społeczności, w której żyją, uczą się czy pracują.

Reasumując, problematyka podjęta w opracowaniu - zarysowana w tytule głównym - wydaje się być bardzo interesująca i potrzebna w dyskursie pedagogicznym na temat kondycji współczesnej młodzieży. Spis treści i zawarte w nim tytuły poszczególnych tekstów wskazują na wieloaspektowe i wielowątkowe podejście do zagadnienia aktywizacji młodzieży w warunkach zmiennej rzeczywistości społeczno-kulturowej. Wskazują ponadto na poznawczy i utylitarny charakter tekstów, które mogą stanowić inspiracje dla pedagogów teoretycznie i empirycznie zorientowanych. 


\section{Ocena szczegółowa monografii - poszczególnych jej tekstów}

Całość złożona jest z Wprowadzenia oraz 12 tekstów powiązanych z tematem głównym. Na końcu zamieszczone zostały noty o autorach - to prawie w całości pracownicy naukowi Wydziału Studiów Edukacyjnych Uniwersytetu im. Adama Mickiewicza w Poznaniu, pedagodzy, których zainteresowania badawcze dotyczą problematyki młodzieży; jedna z autorek reprezentuje Akademię Ignatianum w Krakowie. Teksty powstały w wyniku prac badawczych skupionych wokół prof. dr hab. Agnieszki Cybal-Michalskiej, która przewodniczyła Zespołowi Pedagogiki Młodzieży działającemu przy Komitecie Nauk Pedagogicznych Polskiej Akademii Nauk. To uznany w pedagogice autorytet, także w zakresie problematyki młodzieży.

We Wprowadzeniu autorki opracowania wyjaśniają zasadność podjęcia problematyki młodzieży, zwłaszcza w aspekcie jej aktywizacji w środowisku życia w kontekście zachodzących zmian społeczno-kulturowych, które kreują postawy i zachowania młodych ludzi. Podkreślają przy tym znaczenie pedagogiki społecznej - jej funkcji i zadań w procesie animacji/aktywizowania młodzieży do działań zmieniających otaczającą rzeczywistość społeczno-kulturową, a także zmianę samych siebie. Zadaniem pedagogów jest odpowiedzialne wprowadzenie młodych ludzi w tę rzeczywistość, wspieranie ich w aktywności pożądanej (społecznie, pedagogicznie), natomiast eliminowanie/uświadamianie zagrożeń.

Pierwszy tekst autorstwa A. Cybal-Michalskiej nosi tytuł Młodzież na drodze przejścia z edukacji na rynek pracy. Problematyka tranzycji z edukacji na rynek pracy stanowi ważne zagadnienie pedagogiczne dotyczące dwóch wymiarów: edukacji i rynku pracy, który jest różnorodny i staje się coraz bardziej elastyczny. Autorka wyjaśnia tutaj pojęcie tranzycji jako przejścia ze szkoły do pracy (OECD), opisuje dotychczasowe badania na ten temat (w polskiej i zagranicznej literaturze) wskazujące na trend coraz większej różnorodności w ścieżkach przejścia z edukacji do pracy (przedłużające się okresy kształcenia, okresy bezrobocia, prace „zleceniowe” niedające młodemu człowiekowi stabilizacji), a także różnego typu uwarunkowania tego procesu, problemy, które młodzi ludzie powinni umieć rozwiązywać. Autorka wymienia konkretne techniki, które mają ich wspierać w przejściu ze szkoły na rynek pracy, m.in. poprzez zdobycie konkretnych kompetencji (zindywidualizowane taktyki socjalizacyjne prowadzące do zachowań proaktywnych). To bardzo interesujący poznawczo tekst, napisany na podstawie polskiej i zagranicznej literatury, w którym widać bardzo dobre rozeznanie autorki w podejmowanej problematyce.

Kolejny tekst pt. Znaczenie jakości komunikacji interpersonalnej $w$ kierowaniu organizacjami młodzieży został napisany przez K. Segiet. Można w nim dostrzec walor praktyczny, ponieważ wiedza o komunikacji interpersonalnej, jej funkcjach, stylach czy formach komunikowania się decyduje o sprawnym/właściwym funkcjonowaniu organizacji, także organizacji młodzieżowej. Autorka charakteryzuje wybrane modele, sposoby i style komunikowania się ludzi w organizacji, dostarczając tym samym wiedzy, która może być wykorzystana w procesie kierowania organizacją młodzieżową. Artykuł napisany został na podstawie fachowej/tematycznej literatury przedmiotu, umiejętnie wykorzystanej w dyskusji, której się podjęła w prezentowanym artykule.

K. Węc to autorka kolejnego tekstu pt. Tyrania aktywności - pomiędzy Wyobrażeniowa a Realna możliwościa egzystencji podmiotu. Hermeneutyczne konteksty pragnienia uwikłanego $w$ dyskurs Innego. Prezentowany artykuł ma charakter teoretyczny, proponowana przez autorkę perspektywa poznawcza osadzona jest w dyskursie psychoanalizy Lacanowskiej, która została tutaj potraktowana jako narzędzie językowe i interpretacyjne. Analiza Lacanowskiego rozumienia podmiotu oraz figury 
Innego prowadzi autorkę do wniosku, że ma ono szczególne znaczenie dla pedagogiki - procesu wychowawczego. Stara się to udowodnić, przytaczając argumenty za stawianą przez siebie tezą. Interesujące są zwłaszcza rozważania dotyczące wychowania rozumianego jako współbycie Innego (wychowawcy) z podmiotem (wychowankiem) a działaniem uruchamianym przez Innego, tj. człowieka nieznaczącego dla podmiotu. A także rozważania dotyczące aktywności jako fenomenu kulturowego i potrzeby edukacyjnej prowadzone na podstawie poglądów wybranych filozofów, pedagogów, psychologów. Omawiany tekst zachęca, inspiruje do poszerzenia wiedzy pedagogicznej w zakresie aktywizacji podmiotów/wychowanków przy wykorzystaniu koncepcji Jaques’a Lacana.

Kolejny tekst, autorstwa K. Słupskiej, został zatytułowany Aktywizacja młodzieży w środowisku lokalnym - różnorodność sposobów działania. Zawarte są tutaj interesujące (punkt widzenia pedagogiki społecznej) rozważania dotyczące partycypacji i jej znaczenia w życiu młodych ludzi. Autorka podaje przykłady zaangażowania młodzieży w projekty społeczne, edukacyjne, kulturalne, realizowane w konkretnych środowiskach lokalnych. Wskazuje na korzyści, jakie młodzi ludzie osiągają poprzez uczestnictwo w różnego typu projektach realizowanych w środowiskach lokalnych. Tekst został napisany z dużą erudycją, znawstwem problematyki, a także wykorzystaniem bardzo bogatej bibliografii.

Aktywizowanie i organizowanie społeczności lokalnej jako problem pedagogiczny to tytuł następnego tekstu, autorstwa K. Pawełek. To interesujący tekst dla pedagogów, zwłaszcza pedagogów społecznych ( $w$ tym praktyków, animatorów, liderów), którzy angażują się bezpośrednio w wyzwalanie „kapitału społecznego” w jednostkach, grupach społecznych, szerszych społecznościach wchodzących w skład środowiska lokalnego. Autorka charakteryzuje strategie działań prowadzonych na poziomie lokalnym, aktywizację ludzi poprzez zwiększanie ich motywacji, wzrost zaangażowania, a także wykorzystanie gotowości do pracy czy działań społecznych. Artykuł został napisany na podstawie bardzo obszernej/bogatej literatury przedmiotu. Rozważania autorki są interesujące poznawczo, mogą także stanowić inspirację dla pedagogów-praktyków, którzy uczestniczą bezpośrednio w realizacji projektów społecznych aktywizujących społeczności lokalne.

Artykuł autorstwa K. Segiet i P. Głowackiej nosi tytuł: Zasoby wychowania i wsparcia jako korzystne potencjały dla wspomagania rozwoju młodzieży i źródło aktywizacji środowiska. Została w nim zaprezentowana perspektywa pedagogiki społecznej. Autorki wyjaśniają tutaj kluczowe kategorie tej subdyscypliny, tj. środowisko społeczno-wychowawcze, zasoby wychowania, wsparcie oraz kategoria aktywizacji w kontekście wychowania i wsparcia młodzieży w jej środowisku życia. Akcent został położony na promowanie postaw twórczych u młodzieży i więzi społecznych. Rozważania autorek prowadzone są na dobrym poziomie merytorycznym, $\mathrm{z}$ dobrą argumentacją naukową stawianych kolejno tez.

Kolejny tekst pt. Czas wolny młodzieży ze szczególnym uwzględnieniem jej miejskiej reprezentacji został napisany przez A. Matysiak-Błaszczyk i M. Zychowicza. Podjęta w nim problematyka jest bardzo aktualna na gruncie wielu nauk, zwłaszcza w pedagogice społecznej. Autorzy dokonują tutaj przeglądu czasu wolnego młodzieży zamieszkującej w środowiskach miejskich. Wskazują na organizację czasu wolnego, jego budżet oraz problemy, jakie się z tym wiążą w kontekście miasta jako środowiska życia, edukacji, socjalizacji, uczestnictwa w kulturze i innych, które są korzystniejsze niż w środowiskach wiejskich czy małomiasteczkowych. Rozważania poparte zostały konkretnymi przykładami badań dotyczących wykorzystania czasu wolnego przez młodzież w środowiskach miejskich. Autorzy wskazali także na Internet/Sieć, a zwłaszcza portale społecznościowe, w których aktywnie uczestniczą młodzi ludzie, a które mogą stanowić dla nich zagrożenie. Rola pedagogów $\mathrm{w}$ procesie aktywizacji młodzieży w czasie wolnym jest ogromna, powinna być także profilaktyczna, 
edukacyjna, zwłaszcza w przypadku Internetu, który jest w życiu współczesnej młodzieży wszechobecny. Omawiany tekst ma walor poznawczy i praktyczny. Stanowi ważny głos w pedagogicznym dyskursie dotyczącym czasu wolnego młodzieży, jego funkcji, organizacji, budżetu oraz form, a także zagrożeń.

P. Peret-Drążewska to autorka następnego tekstu pt. Tożsamość młodzieży partycypującej we współczesnej rzeczywistości społeczno-kulturowej. Ma on charakter teoretyczno-empiryczny. Refleksja autorki dotyczy teoretycznych ujęć tożsamości, adolescencji jako okresu krystalizacji tożsamości, dylematów tożsamościowych we współczesnej rzeczywistości społeczno-kulturowej. Przytaczane wyniki badań zawierają analizę subiektywnego aspektu poczucia tożsamości współczesnej młodzieży, która jest wielokontekstowa. Poruszony w artykule problem tożsamości młodzieży, adolescentów jest bardzo istotny dla rodziców, pedagogów, którzy uczestniczą w procesie wychowania młodych ludzi i których zadaniem jest wspieranie młodych w tożsamościowych zadaniach rozwojowych. Tekst dotyczący tożsamości młodzieży partycypującej we współczesnej rzeczywistości społeczno-kulturowej stanowi ważny głos w dyskursie pedagogicznym dotyczącym obrazu współczesnej młodzieży, kształtowania się tożsamości młodych ludzi (odpowiedź na pytanie: „kim jestem?”, która jest kluczowa dla ich samooceny, obrazu siebie oraz funkcjonowania społecznego).

Artykuł pt. Kondycja młodzieży z zespołu szkół zawodowych - przyczynek do dyskusji nad zadaniami stawianymi przed wspótczesnym szkolnictwem zawodowym został napisany przez L. Myszkę-Strychalską. To interesujące rozważania teoretyczno-empiryczne (z wykorzystaniem wyników badań ogólnopolskich, raportów), w których autorka inicjuje dyskusję o kształceniu zawodowym w Polsce, w tym także doradztwie zawodowym prowadzonym na wcześniejszym etapie kształcenia. Charakteryzuje propozycję dualnego modelu kształcenia do zawodu - status pracownika i ucznia, który jest korzystny dla młodych ludzi - łączenie szkolenia teoretycznego i praktycznego kształcenia zawodowego. W artykule została wykorzystana bogata fachowa literatura przedmiotu. Rozważania tutaj zawarte, oprócz waloru teoretyczno-poznawczego, mają także walor praktyczny - dla pedagogów, decydentów resortu edukacji.

W tekście pt. Samorzad uczniowski metoda wychowawczą. Bogata przeszłość, uboga teraźniejszość autorstwa M. Kiszki poruszona została ważna pedagogicznie, edukacyjnie problematyka samorządności młodzieży. To, w ocenie autorki, jedno z najtrudniejszych zadań współczesnej szkoły. Na wstępie przedstawione zostało rozumienie pojęcia samorzą uczniów, natomiast w dalszej części rozważań znajduje się opis głównych założeń oraz funkcji samorządu uczniowskiego. Szczególnie wartościowa poznawczo jest ostatnia część artykułu zatytułowana Wychowanie w duchu samorzadności przygotowaniem do uczestnictwa $w$ demokracji uczniowskiej. Autorka wskazuje na samorządność jako jedną z ważnych metod wychowawczych, przygotowujących młodych ludzi do dorosłości, aktywnego udziału w życiu społecznym - demokracji uczestniczącej. To interesujące rozważania, adresowane głównie do praktyków edukacji, nauczycieli i wychowawców szkół (podstawowych, średnich).

Tekst pt. Aktywizacja społeczna młodzieży uczęszczającej do Ośrodków Kuratorskich został napisany przez A. Matysiak-Błaszczyk. Przedstawione w nim zostały wybrane formy aktywizacji młodzieży uczęszczającej do ośrodków kuratorskich. Autorka charakteryzuje tutaj działalność takich ośrodków oraz ich funkcje. Formułuje także rekomendacje dla praktyki funkcjonowania tego typu placówek w kontekście ich celów. Jednym z nich jest przygotowanie młodzieży problemowej do pełnienia akceptowanych społecznie ról życiowych poprzez oddziaływania wychowawczo-resocjalizacyjne połączone z programami aktywizacji zawodowej umożliwiającymi znalezienie pracy w warunkach gospodarki rynkowej. Omawiany tekst jest kierowany do pedagogów, zwłaszcza reso- 
cjalizacyjnych, którzy pracują bezpośrednio z młodzieżą problemową. Ma on wyraźnie charakter praktyczno-użyteczny, tak ważny w praktyce pedagogicznej.

Ostatni tekst zamieszczony w opracowaniu pt. Młodzież dla seniorów - wybrane aspekty (perspektywa pedagogiczna) został napisany przez dwie autorki - A. Tokaj i E. Włodarczyk. Zawiera on interesujące - dla pedagogiki i pedagogów - rozważania dotyczące wsparcia seniorów w ich codziennym życiu poprzez działania młodzieży, która jest aktywna społecznie, wolontaryjnie. Autorki wymieniają korzyści dla młodych ludzi angażujących się w działania dla seniorów i z seniorami. Wskazują na różne - szkolne i pozaszkolne inicjatywy, które pozwalają młodym ludziom działać prospołecznie. Artykuł ma walor praktyczny - pedagogicznie, edukacyjnie, metodycznie. Oceniam go jako przydatny dla teoretyków i praktyków wychowania młodzieży.

\section{Konkluzja}

Opracowanie pt. Aktywizacja młodzieży w warunkach zmiennej rzeczywistości społeczno-kulturowej, którego redaktorkami są: A. Cybal-Michalska, K. Segiet i K. Węc, oceniam jako ważne i potrzebne dla pedagogiki w jej aspekcie teoretycznym i praktycznym. W tekstach tutaj zawartych znajdują się zagadnienia związane z aktywnością polskiej młodzieży (wartościami, które jej przyświecają), uwarunkowaniami, a także zagrożeniami. Wartość merytoryczną/pedagogiczną zamieszczonych tekstów należy ocenić wysoko. Rozważania prowadzone są na bardzo dobrym poziomie naukowym (język, argumentacja). Mają one także walor praktyczno-użyteczny.

Aktywizacja współczesnej młodzieży, jej partycypacja w życiu społecznym (demokratycznym) to ważny pedagogicznie i społecznie temat, który uznawany jest na gruncie nauk pedagogicznych, zwłaszcza w pedagogice społecznej, jako jedno z zadań wychowawczych - konieczne do życia w społeczeństwie demokratycznym.

Opracowanie skierowane jest do szerokiego grona odbiorców: pedagogów, socjologów, polityków społecznych, decydentów, nauczycieli-wychowawców, studentów nauk społecznych, zwłaszcza pedagogiki, socjologii edukacji oraz młodzieży, dla której teksty tutaj zawarte mogą być inspiracją do podejmowania różnego typu działań/aktywności w środowiskach życia, studiowania, pracy itd. Rekomenduję prezentowaną monografię dla szerokiego grona Czytelników, ponieważ uważam ją za wartościową poznawczo oraz przydatną dla teorii i praktyki pedagogicznej.

DOI: $10.14746 / p s n .2021 .1 .13$

Bożena Matyjas 